\title{
China’s Justice Practice: Towards the Adversarial Process
}

\section{$\mathrm{Na} \mathrm{Jiang*}$}

Associate Professor of College for Criminal Law Science, Beijing Normal University, Beijing, China

\begin{abstract}
This paper examines practice on China's undergoing reform on criminal law and criminal justice, particularly on non-adversarial controls retained in its road towards the adversarial system, in order to explore into the major obstacles of, and certain potential for, its transition towards adversarial processes. It will be suggested that further reform should be promoted to mend such flaws in both law and practice concerned. Also, the suspension of an immediate moratorium on executions and the increasing of more transparency and judicial independence are of great significance and in urgent need to better protect human rights of the accused, including those facing the death penalty.
\end{abstract}

\section{Present Situation}

Due to the severe lack of legal safeguards and above-mentioned breaches of current law, the practice would not guarantee due process in all criminal trials, including those resulting in death sentences. The criminal justice system remains highly vulnerable to corruption and political interference, so that the police, procuratorate and courts are not independent and remain under the supervision of the Chinese Communist Party. Under the current political and judicial systems, Party and government organisations may interfere with criminal trials and there might have political pressure to pass death sentences, as demonstrated from wrongful convictions frequently reported in recent years of China.

\section{The first category of rights}

In practice, the PCs seems to ensure the right of those facing the death penalty to call, obtain the attendance of, and examine witnesses, in order to keep a balance between the accusing and defending parties in hearing capital cases that should be prosecuted and supervised by the PPs, rather than all of criminal cases. However, the PPs are likely to optionally prosecute the criminal responsibility of witnesses and the PCs might have a negative attitude towards the testimony of the defendants. This would lead to the serious imbalance between them and actually not to effectively protect the right to call and examine witnesses. Moreover, a lack of legal safeguards or protective measures for preventing attacks against, or interference with witnesses, appears to lead to a low participation of them in court. This might not fully safeguard the above right, but aggravate the imbalance between both parties in criminal cases. This also appears to lead to the high rate of conviction, a nearly 100 per cent in criminal cases of China every year, i.e., exactly 99.9 percent in 2009 , of the combined conviction rate for criminal trials in the first and second instances, according to the China Law Yearbook.

Furthermore, the approach of written examination, potentially adopted in the ordinary procedure of second instance and that for review of death sentences, appears to breach the right of the accused to cross-examination of witnesses. Relevant evidence without crossexamination and even illegal evidence tend to be adopted as the evidence that could be used to determine a case. Additionally, the system of legal aid, applicable to several kinds of criminal cases, merely exists in the trial phase, instead of for the whole course. The right to legal aid would not be effectively safeguarded. With the late establishment of this system and backward conditions in some parts of China, the fund dedicated to it appears to be very meagre. Thus, the system tends not, in practice, far from meeting social needs. These obstacles are likely to lead to sudden convictions in the first instance, no actual function of the second-instance procedure, or no acceptance of justified defence opinions. This restricts the effective practice of this right in the first and second instances of criminal cases, not to mention the procedure for review of death sentences.

\section{The right to appeal}

Among the second category of rights, the right to appeal is at the core of criminal justice, of which the present practice could be demonstrated from the following advantages and disadvantages. China tends to fully safeguard the legal right of appeal to examine legally improper death sentences in the procedure of the second instance or legally effective ones in the procedure of trial supervision. In practice, $99 \%$ of defendants exercise this right to initiate procedures for the second instance, with the principle that no appeal will result in additional punishment, contributing to the effective protection of this right and promoting the justice of criminal sentences.

Yet, in most circumstance, it seems to be difficult for them to successfully exercise this right in the proper period following the sentence for several reasons. The limits on meeting between defence lawyers and the defendants appear to obstruct lawyers in helping defendants serving death sentences with a suspension of execution to actually exercise this right. Although a party or near relative of the defendants often takes the initiative in starting the procedure for trial supervision, some judicial bodies appear unwilling to accept the appeal, considering their own interests and possible State compensation, and thus few appeals tend to be accepted in fact. Even if re-examining the appeal by the defendant, the PPs tend to disregard the defendant party's appeals after accepting, much less protesting against legally effective death sentences. They also pay more attention to supervision over cases involving under-punishment, whilst at the same time paying less attention to over punishment, indicating the tendency of starting

*Corresponding author: $\mathrm{Na}$ Jiang, Associate Professor of College for Criminal Law Science, Beijing Normal University, China, Tel: 01058802774, 13261991907; E-mail: na.jiang@bnu.edu.cn

Received June 04, 2014; Accepted September 30, 2014; Published October 07, 2014

Citation: Jiang N (2014) China's Justice Practice: Towards the Adversarial Process. Intel Prop Rights 2: 130. doi:10.4172/2375-4516.1000130

Copyright: (c) 2014 Jiang N. This is an open-access article distributed under the terms of the Creative Commons Attribution License, which permits unrestricted use, distribution, and reproduction in any medium, provided the original author and source are credited. 
the retrial procedure against the defendants, e.g., no change of all members in the collegial bench of retrial, against 1996CPL Article 192. Some courts tend not to cancel death sentences that have been issued, considering their collegiate interests, which appears not to correct all misjudged death sentences that might be found.

\section{The third group of rights}

A public trial: Criminal cases are universally held in a public hearing in the first instance. Although, according to the law, those involving State secrets, private affairs of individuals, or juveniles below 18 years of age shall not be heard in public, the HPCs in the second instance tend not to hold a public hearing in court, but read files, interrogate the defendant, and investigate the case, in contrast to 1996CPL Article 187. Some defenders have to present written opinions in their defence to second-instance courts, which appears not to adequately ensure the right to defence. This written approach seems merely to contribute to speeding up the period of concluding capital cases and reducing procedural costs, whereas without the presence of the defendant and cross-examination of the two parties, the trial tends not to ensure the just application of sentences, but instead increases misjudged cases. Since the second half of 2006, all HPCs have taken the approach of public hearing in trying any second-instance case involving death sentences.

This procedure for review of death sentences is unable to offer a public hearing with both parties in attendance, but takes the approach of a secret reading by the SPC or HPCs. This appears to breach the right to a public hearing. Without transparency or openness, the PCs tend to dominate the whole course of affairs, and the defendant has to passively wait outside for the final results of verdicts. A lack of the effective participation of the defendants and of cross-examination of two parties tends to go against the minimum guarantees of procedural justice. These might increase the difficulty in discovering misjudged death sentences and the possibility of the arbitrary deprivation of the right to life.

An independent and fair trial: There seems no independent or impartial trial in criminal proceedings, especially in capital punishment cases, for several reasons. Firstly, the system of collective trial inside judicial bodies tends to strengthen the control of judges by means of decision-making by a collegial benches or trial committee. This is designed to draw on the wisdom of the masses and reduce misjudged cases, while presiding judges cannot make sentences impartially, nor can the members of trial committee attend trials. Such a trial is against criminal justice.

Secondly, lower courts tend to report to upper ones and ask for instructions with respect to both legal and factual problems, and upper courts investigate into misjudged cases sentenced by lower courts. This dependent relation between them at diverse levels appears to indicate that lower courts are under the guidance, rather than the supervision, of upper ones in decision-making.

Thirdly, judicial bodies have long been regarded as political tools under the absolute guidance of party committees in judicial work since 1949, which leads to a lack of due respect for laws, courts and for independent justice. The leadership of the Chinese Communist Party (CCP) abolished the system of party committees examining and approving particular cases in public proclamation in the early 1980s. Yet in fact the committee of the same or upper level still directly intervenes in sentences of momentous or sensitive cases, and main cadres appear to oppugn concrete trials. With the mainstream idea of judicial independence in political circles, politics and law committees inside party committees of all levels, mainly discuss and submit some great or momentous cases to party committee of the appropriate level for decision-making. This might have a negative influence on an independent and impartial trial.

Fourthly, the good training of judges themselves contributes to an impartial trial, but not all Chinese judges have good training. Since it seems difficult for unqualified judges to try capital cases without the help of colleagues, leaders or upper courts, this might lead to the partiality of judges in hearing cases and making judgements.

Fifthly, the local People's Congress tends to select judicial personnel from local State bodies, which is likely to lead to a mixture of qualified and unqualified judges, or even, in some areas, an entirely poor collection of judicial personnel. The People's Congress also has the power to supervise all stages of judicial proceedings. These would influence the independence of courts. Since legislative bodies represent public opinions that are not always consistent with judicial justice, they might change the impartial position of judges to make unjust judgements.

Nulla poena sine lege: In practice, judges tend to convict and punish criminals strictly pursuant to the criminal laws concerned, which seems to present one side of the basic situation on practising the principle of nulla poena sine lege in China. The other side involves several disadvantages and problems as follows. Under the current political systems, it still remains a serious problem that Party and government organisations interfere with the independent practice of the prosecutorial and judicial power. The senior leadership paid more attention to the behaviours of some local officers, while it is not rare for courts to convict persons for activities not punishable by laws or to conclude the verdict of not guilty even though the law stipulates them to be crimes. This problem may exist in capital cases, as reported in recent news on Case Wu Ying with lawyers' defense for innocence, which was remanded by the SPC for a retrial at the HPC of Zhejiang Province, without approval of her death sentences in the procedure for a final review, on 20 April 2012 [1].

Moreover, not all judges are able to strictly explain laws in favour of the defendants [2], so that another problem appears on the tendency to give heavy punishments to the suspects, regardless of their innocence or guilt. In recent years, the media have reported more cases of courts sentencing the innocent to death. In fact, the innocent find it impossible to tell their own side of the story, and guilty suspects are unwilling to present evidence and facts for fear of incriminating themselves, but offer untrue oral confessions or overthrow the true one. This tends to be regarded as a bad attitude which leads to heavy punishments and the expansive application of death sentences.

\section{After Reforms}

Immediately followed by official correction of famous miscarriages in Cases SHE and ZHAO, respectively declared innocent in 2005 and 2010, the SPC subsequently took great efforts to reform the procedures for handling capital cases or rules of examining and evaluating criminal evidence in various forms. Since it further promoted the adoption of Amendment VIII to Criminal Law and Amendment II to Criminal Procedure Law of the PRC, relating to the prevention of miscarriages in capital cases in 2011 and 2012, a series of satisfying impact or significant progress on this issue is expected to be achieved as its actual effect. But in fact, the resultant culture of secrecy and sheer lack of publicly available data tend to seriously hinder any independent assessment on the relevant practice after reforms, thereby impeding definitive, empirically-based conclusions on the current practice as the concrete 
effect of recent legislative and preventive measures. Hence, case studies on available reports might be alternative ways of making convincing analyses and examinations on the actual effect of these reforms.

\section{Case one: TAO jianhua}

On 28 June 2007, Chinese state media reported the first execution in Beijing following the restoration of SPC review [3]. TAO Jianhua was executed by the Beijing No.2 IPC for murder after his sentence had been approved by the SPC. As an official media reported, the second instance court in open session heard the details of the case, overruled his appeal to maintain death sentences in the original judgment of first-instance court, and reported to the SPC for its review of the death penalty, according to the newly implemented procedure, on 8 March 2007 [4]. While some reports provided information about the SPC review process in general, they did not include specific procedural details about TAO Jianhua's case, including whether he or his lawyer were able to make representations to the SPC review panel. While Chinese legal commentary suggests that defendants' lawyers are allowed to make representations during the review, it remains unclear whether or not this is happening in practice [5].

The above case appears to present the positive progress of current situation on the strict process of capital cases that have been heard and reviewed in Beijing, after China's recent reforms on the relevant procedures for handling capital cases. In apparent recognition of the need for greater transparency at lower levels, the SPC issued a legal notice on 14 June 2007 stressing that first-instance death penalty cases must be held in open court and that courts should move towards ensuring public trials for appeal hearings in criminal cases more generally [6]. The notice also called for more in-court announcements and wider publication of judgments. This followed an SPC ruling last year that all second-instance hearings of death penalty cases (ie appeals) should be held in open court from 1 July 2006 in a stated attempt to improve protection of human rights and safeguard against miscarriage of justice. Such reforms would hopefully result in better quality trials and a significant reduction in the number of those sentenced to death and executed.

Considering unclear reports on the specific details of the procedure for review of death sentences in capital cases, however, the second instance death penalty hearings may still be held in camera in some parts of China despite this ruling, under the shelter of the authorities' failure in disclosing full statistics concerned. Such concerns were underscored on 23 June 2007, when Chinese state media quoted an unnamed local court source who stated that understaffing often made it impossible to try death penalty cases in open court sessions [7]. 'If second instance trials are not heard openly, the public do not feel convinced--the process is not transparent, the rights and interests of the accused are not fully protected, and judicial errors could occur' [8], consequently China's courts needing hire 1,900 more staff for an open trial of second instance death penalty cases.

\section{Case two: LENG guoquan}

Leng Guoquan, a seafood trader, was sentenced to death on 16 December 2009 by the Dandong City IPC in Liaoning province. He was charged with being a leader of a criminal gang engaged in smuggling and trafficking drugs. His conviction followed an unfair trial, and was based on his confession and testimonies from witnesses who have either subsequently retracted their statements or say they were tortured into testifying against him.

Leng Guoquan himself has always denied the charges and says he confessed because he was tortured. Detained on 19 January 2009, Leng Guoquan said he was tortured for three days and three nights while being interrogated by a special police unit. Three police officers bound his hands behind his back. They pushed his head between his legs and punched him. Later, they lit one end of a tube of rolled paper and stuffed the other end into his nose, covering his mouth until he was forced to breathe in the fire. Since January 2009, Leng Guoquan has been interrogated and tortured several more times. Leng Guoquan has been held at the Fengcheng County Detention Centre since 2009. He was first registered under a false name (Chen Dong), apparently in an attempt to prevent his lawyer and family from finding out where he was held. Since discovering his location, his family have not been allowed to visit him.

His family have appointed four different lawyers to represent him. The judicial authorities forced the first one to resign after he took pictures of LENG Guoquan's scars which he said were a result of torture, while the second and third were denied access to him. The fourth lawyer eventually gained access and met him before his first trial. This lawyer filed a complaint with the Dandong City Procuratorate in July 2009 claiming that his client had been tortured in custody and calling for an investigation. In August 2010, the Liaoning Provincial Procuratorate concluded that the allegations of torture were unfounded.

At the trial, LENG Guoquan's lawyer had no chance to crossexamine key witnesses. Those who did testify retracted their previous statements. LENG Guoquan's co-defendant said that he had been tortured into confessing. Another witness also said that he had given the police false information. The prosecution did not provide any material evidence to support witness statements (which were subsequently withdrawn) that claimed he was guilty.

At his appeal hearing on 7 December 2010 at the Liaoning Provincial HPC, LENG Guoquan showed the court the scars on his head, wrists and legs he said were inflicted through torture. Of 56 witnesses called by the defence, only three were heard by the court. On 6 May 2011, the Liaoning court sent LENG Guoquan's case back to the Dandong City IPC for re-trial due to "lack of clarity about the facts" and "lack of evidence." The re-trial took place on 10 October 2011 and the IPC sentenced him to life imprisonment in the first instance on 23 November 2011 [8], without a further report on the second-instance judgments of this case till now.

From the above details of this misjudged case, reasons for wrongful convictions may appear in any link or different stages of criminal proceedings. In China, false confessions tend to be the largest source of miscarriages of criminal justice and quality control should start from investigation, considering routine and widespread use of torture and ill-treatment of suspects in police custody, especially to extract confessions or information to be used in criminal proceedings [9]." Such factors that facilitated its use appear to include that evidence rules creating incentives for interrogators to illegally obtain confessions, the excessive length of detention time without judicial control, the absence of a legal culture based on the presumption of innocence; and restricted rights and access of defence counsel. Hence, the Amendment (amended Article 34) require not only the Courts, but also the Procuratorate and the Police to inform legal aid organs to provide a defense lawyer for all suspects or defendants who potentially face life imprisonment or the death penalty and have not themselves designated a defender. Regrettably, without a concomitant responsibility of the legal aid organization or time frame for their compliance, it would be desirable for further reforms to establish legally aided defense available 
at all stages of process in capital cases and delineate the role of defense lawyers in the appeal and final review process.

\section{Conclusion}

As individuals suspected of committing a crime proceed through the criminal justice system in China, their progress is marked by numerous violations of their fundamental human rights, detrimental to a designed balance of the accused, procuratorate and court in a triangular structure. These rights are violated not only in contravention of international standards including binding legal obligations undertaken by the Chinese government, but also in contravention of China's own national laws.

However, even if criminal proceedings were handled strictly by law, the variance of these laws would still leave scope for continued miscarriages with China's de-centralised, overtly politically influenced and poorly funded systems of justice, as indicated and underlined by a series of famous wrongful convictions. The effectiveness of criminal procedure laws in practice is in any case dependent on a broader institutional framework within which the laws operate, including an independent and impartial judiciary as the cornerstone of a fair trial and due process. Unfortunately, serious obstacles still exist in China, of which the first and foremost could be the long-established supremacy of the CCP in power over the rule by law, resulting in the fact that some judges tend to apply the law in accordance with Party policy or the interests of local Party.
In conclusion, for creating watertight safeguards against miscarriages of justice, thorough reforms on laws and practices are needed and seem to be a long-term process in China. Therefore, an immediate moratorium on executions would be helpful to reduce catastrophic failures in its criminal justice system highlighted above, as the first step towards its gradual abolition of the death penalty.

\section{Reference}

1. Huaxin Z (2012) Internet Users Not to Misread the SPC's Review of Case Wu Ying, China Youth News, 21th April 2012.

2. Ibid.

3. First death penalty prisoner executed in Beijing following restoration of SPC review, China Youth Daily, 28 June 2007; also This year's first death penalty prisoner executed this morning, Legal Evening News, 27 June 2007.

4. First execution in Beijing following the SPC's restoration of the power to review death sentences, Beijing Evening News, 27 June 2007.

5. ASA 17/015/2007, p.6.

6. Capital cases made more transparent, China Daily, 15 June 2007.

7. China's courts recruit more staff for death penalty reviews, Xinhua, 23 June 2007.

8. Case LENG Guoquan Changed to Life Imprisonment for Drug Smuggling and Trafficking in the First-Instance of Its Retrial.

9. Concluding Observations of the Committee against Torture: China. UN Doc. CAT/C/CHN/CO/4, 12 December 2008, para.11. 